\title{
Does Job Satisfaction Mediate the Effect of Role Stressors on Employee Turnover Intention in Hotel Businesses?
}

\author{
Nagihan ÇAKMAKOĞLU ARICI iD a \\ a T.C. Stuttgart Başkonsolosluğu Eğitim Ataşeliği, Stuttgart, Almanya. heraas1983@yahoo.com
}

\begin{tabular}{|c|c|}
\hline ARTICLE INFO & ABSTRACT \\
\hline \multirow{4}{*}{$\begin{array}{l}\text { Keywords: } \\
\text { Role stressors } \\
\text { Job satisfaction }\end{array}$} & \multirow{3}{*}{$\begin{array}{l}\text { Purpose - The research aims to test the mediator role of job satisfaction in predicting turnover } \\
\text { intention and role stressors (role conflict, role overload, role ambiguity, job security and career } \\
\text { opportunity) relationship by frontline employees. }\end{array}$} \\
\hline & \\
\hline & \\
\hline & \multirow{4}{*}{$\begin{array}{l}\text { Design/methodology/approach - This research has adopted a descriptive research investigating } \\
\text { the relationships between role stressors and employee turnover intention. A total of } 226 \text { frontline } \\
\text { employees from four- and five-star hotel businesses in Antalya, Turkey have been surveyed by } \\
\text { using a questionnaire. To test the internal consistency of the survey items, reliability and validity } \\
\text { analyses were performed by using alpha coefficient values and factor analysis. In addition, the } \\
\text { data were analyzed by using correlation and regression analysis. }\end{array}$} \\
\hline Turnover intention & \\
\hline Front-line employees & \\
\hline Hotel businesses & \\
\hline Received 10 September 2019 & \multirow{4}{*}{$\begin{array}{l}\text { Findings - This research has adopted a descriptive research investigating the relationships } \\
\text { between role stressors and employee turnover intention. A total of } 226 \text { frontline employees from } \\
\text { four- and five-star hotel businesses in Antalya, Turkey have been surveyed by using a } \\
\text { questionnaire. To test the internal consistency of the survey items, reliability and validity analyses } \\
\text { were performed by using alpha coefficient values and factor analysis. In addition, the data were } \\
\text { analyzed by using correlation and regression analysis. }\end{array}$} \\
\hline Revised 8 December 2019 & \\
\hline Accepted 25 December 2019 & \\
\hline Article Classification: & \\
\hline & \multirow[b]{2}{*}{$\begin{array}{l}\text { Discussion - The study findings confirmed previous studies which suggested that employee job } \\
\text { satisfaction could reduce employee intention to leave the hotel organization. Using this important } \\
\text { finding, researchers and practitioners can improve managerial policies to ensure more satisfied } \\
\text { employees which in turn will result in lower level of employee turnover intention in the hotel } \\
\text { industry. In addition, in the future studies, sample size could be expanded using one of the } \\
\text { probability sampling methods to generalize the study findings. The detailed suggestions and } \\
\text { further directions for such research have been discussed in the discussion section of this study. }\end{array}$} \\
\hline & \\
\hline
\end{tabular}

\section{INTRODUCTION}

Leaving a job is the major reason for existing higher level of turnover intention (TI) for employees especially in the hospitality industry. Increasingly employees face stressful factors that might arise from such conflicts as role conflict (RC), role overload (RO) and role ambiguity (RA). Chen et al. (2011) argued that role stressors are determinants of work strains of employees which also result in lower job satisfaction (JS). Many scholars accept that role strains are composite of role overload, role conflict, and role ambiguity (Kahn, 1980; Kelloway \& Barling, 1990; Schaubroeck et al., 1989). These stressful factors are likely to affect job satisfaction of employees; as a result, if employees feel exhausted and dissatisfied, it will be harmful for the firm's performance. As for role overload, individuals who feel exhausted and frustrated with their positions at work are more probably to hold high intention of turnover and to be absent from their organizations (De Croon et al., 2004). Staff (i.e. front-line employees) turnover influences the quality of their performance negatively and consequently affects the continuity of customer service (Mor Barak et al., 2001). While role conflict is related to two or more positions within the work-place, role ambiguity attributes to lack of clarity. In this respect, Chen et al. (2011) provided that role conflict occurs when an individual is to meet the incompatible requirements and demands of more than two persons (e.g. supervisor and customer) and ultimately turns to be unable to deal with all desires simultaneously. Turnover can be defined as the process in which employees leave the work, and then the organization replaces them. On the other hand, turnover intention is something different and can be described as an employee's intention to find a new job for the 


\section{N. Çakmakoğlu Arıcı 11/4 (2019) 3374-3384}

following periods (Jackson et al., 1987; Mitchel, 1981). Literature studies like Chen et al. (2011) also provide evidence of direct, positive, and significant effects of these role strains on staff turnover intention. Job satisfaction has been inversely linked to turnover intention by employees (Chen et al., 2011).

Career opportunities are also effective in employee job satisfaction level. It is highly likely that the more opportunities employees have in their careers, the more satisfied they will be. Semykina and Linz (2012) found that employees generally get higher satisfaction due to the fact that they have the opportunity to improve their own career. Therefore, it can be argued that career opportunities will influence turnover intention of the employees through job satisfaction. Furthermore, career opportunities and job security are other elements that affect employee satisfaction and therefore their turnover intention. Davy et al. (1997) found significant association between job security and job satisfaction, which provides strong support for the case that job fulfillment mediates the effects of job stability on withdrawal cognitions.

The impacts of two job stressors, job security and career opportunity, on frontline employees' performance, examined in this study have not been conducted previously by the researchers. Employees feel more motive, committed and inclined to stay in their jobs by motivation and higher job security brings about profitable outcomes like a higher job satisfaction and consequently this affects organizational commitment and decrease intention to leave (Chen, 2006; Elangovan, 2001).

The next part comprised the theoretical framework based on two essential theories: 'Personality theory and 'Affective theory' which contribute to the discussion of the gap in this research, followed by the hypotheses of the study. Following section describes the method and findings of the study. The associations were empirically examined via cross-sectional statistic obtained from a sample of front-line staff. The last section is comprised of the implications and suggestions for future research.

\section{THEORETICAL FRAMEWORK AND HYPOTHESES}

The aim of this paper was to examine the effect of role conflict, role ambiguity, role overload, career opportunities, and job security on frontline employees' job satisfaction in the four and five-star hotels in Antalya, Turkey. The mediator effect of job satisfaction on the effects of the above mentioned job stressors on turnover intention was also tested in this study. In the hospitality context of hotels in Antalya, Turkey there existed stress symptoms amongst front-line employees against customers' demands and as a result of low level of organization support. Regardingly, the Personality theory by Kim et al. (2007) argued that so as to avoid the stressors within an organization, all the required tasks should be measured for an individual named "career management skills". According to this theory, personality' is dynamic and varies from person to person and human nature includes similarities and differences, hence, managers should consider this dimension when they recruit employees and train them. How job satisfaction affects the relationship between turnover intention and role stressors in this study was attributed to the Affect theory by Locke (1976) which reveals the variation between what an individual wants from a job and what s/he has in his/her position. Affect theory was attributed in this study to the influence of job satisfaction on core characteristics of staff to perform higher and keep the standard service quality for the customers, increase the employees' psychological involvement to their organization (Carmeli et al., 2010). Therefore, job satisfaction could mediate the association between job stressors and turnover intention.

\section{THE CONCEPTUAL MODEL AND RESEARCH HYPOTHESES}

The proposed model in this paper was presented in Figure 1 and role conflict, role ambiguity, role overload, career opportunities and job security were assumed to be determinants of employee job satisfaction. In the second stage of the analysis, whether job satisfaction as a mediator influenced role conflict and career opportunities on employee turnover intention was examined; hence, the research hypotheses were as follows:

H1a: Role conflict is negatively related to job satisfaction.

H1b: Role overload is negatively related to job satisfaction.

H1c: Role ambiguity is negatively related to job satisfaction.

H1d: Job security is positively related to job satisfaction. 
H1e: Career opportunity has a significant positive influence on job satisfaction.

$\mathrm{H} 2$ : Job satisfaction is negatively related to turnover intention.

H3: Job satisfaction will mediate the influence of job stressors on turnover intention.

Role conflict has been regarded as one of the job stressors in the literature (Chen et al., 2011). Keller (1975) found that role conflict had negative relations with employee job satisfaction. Therefore, this study proposed that role conflict as originated from Rizzo, et al. (1970) would impact employee job satisfaction level negatively.

Role overload has been also regarded as another job stressor in the literature (Chen et al., 2011). It was assumed in this study that since this factor also could cause job stress like role conflict (Chen et al., 2011), it would probably reduce the satisfaction levels of employees. Chou and Robert (2008) empirically proved the negative influence of role overload on job satisfaction of employees. Therefore, it was proposed that this dimension as originated from Caplan, et al. (1975) would reduce job satisfaction in the hotels.

Role ambiguity attributes to vague anticipations from coworkers related to negative work experiences as the job description turns to be confusing due to lack of clarity and ultimately ends up with job stress. Hence, role ambiguity has negative impacts on job attitudes like deterring workers to fulfill their job (Beehr et al., 2000; Stordeur et al., 2001; LePine et al., 2005).

Job security is one of the crucial determinants of job satisfaction no matter which industry employees work in. The higher security employees have in their jobs, the more satisfied they will be. Parvin and Kabir (2011) found that job security had a positive relation with individuals' job satisfaction. Therefore, it was proposed that job security dimension as originated from Oldham et al. (1986) would influence job satisfaction of hotel front-stage staffs positively.

Career opportunities have been connected to job satisfaction in the literature. Ingersoll et al. (2002) found that career opportunities and career intentions of employees positively impacted their job satisfaction. Therefore, it was argued that career opportunities in the case of the hotel industry would result in higher individuals' job satisfaction. The dimension of career opportunities in this paper originated from Bedeian et al. (1991).

Job satisfaction has been linked to employee turnover intention. Mahdi et al. (2012) found that employee job satisfaction reduced turnover intention in the case of the services sector of Malaysia. Therefore, it was argued that employee job satisfaction whose instrument was obtained from Chi \& Gursoy (2009) would reduce turnover intentions in the hotels of Antalya, Turkey as well.

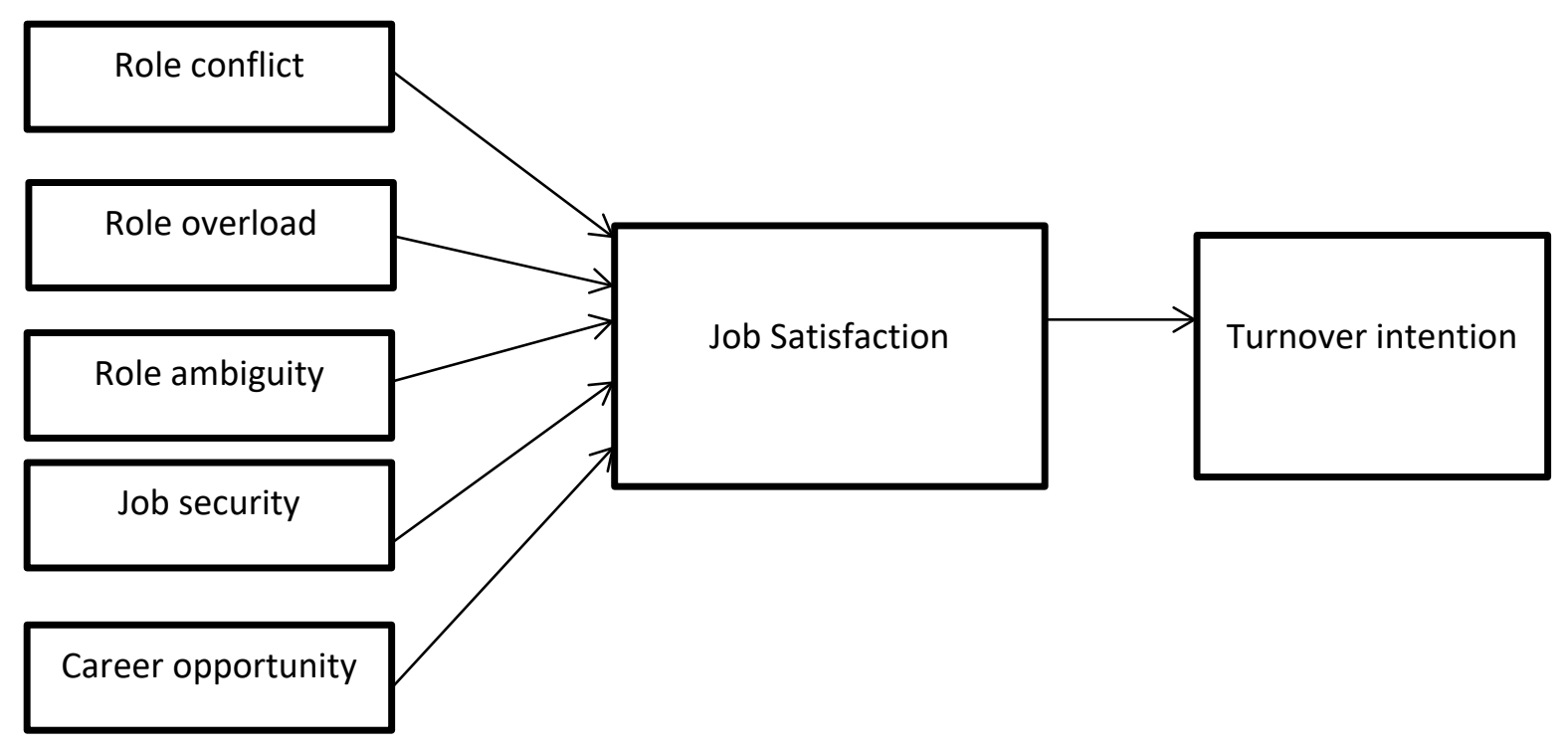

Figure 1. Research model 


\section{METHODOLOGY}

\section{Sample of the Study}

The study hypotheses were tested based on data collected from a sample of hotel frontline employees working in five four-star and seven five- star hotels in Antalya, Turkey during July and August, 2019 through utilizing convenience sampling method. Convenience sampling was used due to time, place, and financial limitations. 260 survey instruments were distributed to frontline employees and a total of 226 valid questionnaires were returned with the response rate of $87 \%$. It was given assurance that the data obtained from the respondents would be only used for this study and would be exactly kept confidential.

\section{Measurement}

In the first part of the questionnaire form, six questions related with demographic characteristics of frontline employees were directed to the respondents, which were gender, age, education, marital status, organizational tenure, and department. The detailed description of these profile questions along with their results were presented in Table 1.

Research instrument was prepared and adapted from the previous studies in the literature composing seven dimensions: Role conflict (8 items) from Rizzo et.al. (1970), career opportunities (5 items) from Bedeian et.al.(1991), role ambiguity (6 items) from Rizzo et.al.(1970), role overload (3 items) from Caplan et.al.(1975), job security (4 items) from Oldham et.al.(1986), job satisfaction (4 items) from Chi and Gursoy (2009), and turnover intention (4 items) from Jackson et al. (1987) and Mitchel (1981). Seven points Likert's scale ranging from (1)-strongly Disagree, to (7)-Strongly Agree. The instrument used in this research was presented in Table 2 providing the results of exploratory factor analysis conducted prior to estimations of linear regression models.

\section{Back Translation and Pilot Study}

In order to measure the convenience of the study items, a pilot study was carried out to 15 front-line employees at 17 hotels of Antalya. The results of pilot study indicated that all items were clear and correct, and the reliability rate of forty items were 0.78 that was acceptable $(>0.7)$.

In this study, the questionnaires were distributed to respondents in Turkish, which were originally arranged in English. All items were translated into Turkish through back translation technique. Also, 2 expert academicians checked the scale to be certain the accuracy of the interpretation of the items.

\section{Data Analysis}

In order to determine the factor dimensions of the study and to evaluate discriminant and convergent validity, exploratory factor analysis was carried out. In this study, when coefficient alphas were tested, the cut-off point was decided as .70. Before the correlation analysis, average scores for each factor were calculated by mean scores of items.

In order to test the hypotheses, linear regression analysis was adapted to this research. The conceptual model of this study and the associations among variables were analyzed through multiple regression analysis. Firstly, the independent variables with the dependent variable were entered in Step 1. Secondly, the impact of the mediator on the dependent variable was tested, and then the mediator was added into the model when the independent variable was controlled.

\section{RESULTS}

\section{Respondents' Profile}

The results regarding the respondents' profile were presented in Table 1 . It shows that $62.83 \%$ of the participants were male and $37.17 \%$ were female. $25.22 \%$ of the participants were aged between of 18-24. 30.97 percent of respondents were between 25-30 years old and the others were over $30.27 .43 \%$ of the respondents had primary school education, $43.81 \%$ had secondary school education, $26.11 \%$ had undergraduate education, $2.21 \%$ had master degrees, and the rest had graduate/doctor degrees. While 41.15 $\%$ of participants were single, $46.90 \%$ were married, and the others were divorced. $68.14 \%$ of the participants had 5 years or less organizational work experience. 30.53 percent of respondents worked at restaurant service, while $23.45 \%$ worked in the culinary department of their hotels. 20.80 percent of respondents worked as front desk clerk, $13.27 \%$ worked in housekeeping department. 8.85 percent of 
N. Çakmakoğlu Arıcı 11/4 (2019) 3374-3384

respondents worked at guest relations department and the rest worked in the other departments of their hotels.

Table 1. Respondents' profile $(n=226)$

\begin{tabular}{|c|c|c|}
\hline & Frequency & Percentage \\
\hline \multicolumn{3}{|l|}{ Gender } \\
\hline Male & 142 & 62.83 \\
\hline Female & 84 & 37.17 \\
\hline Total & 226 & 100.00 \\
\hline \multicolumn{3}{|l|}{ Age } \\
\hline $18-24$ & 57 & 25.22 \\
\hline $25-30$ & 70 & 30.98 \\
\hline $31-36$ & 40 & 17.70 \\
\hline $37-42$ & 33 & 14.60 \\
\hline $43-49$ & 25 & 11.06 \\
\hline 50 and above & 1 & 0.44 \\
\hline Total & 226 & 100.00 \\
\hline \multicolumn{3}{|l|}{ Education } \\
\hline Primary school & 62 & 27.43 \\
\hline Secondary school & 99 & 43.81 \\
\hline Undergraduate & 59 & 26.11 \\
\hline Master degree & 5 & 2.21 \\
\hline Graduate/doctor & 1 & 0.44 \\
\hline Total & 226 & 100.00 \\
\hline \multicolumn{3}{|l|}{ Marital status } \\
\hline Single & 93 & 41.15 \\
\hline Married & 106 & 46.90 \\
\hline Divorced & 27 & 11.95 \\
\hline Total & 226 & 100.00 \\
\hline \multicolumn{3}{|l|}{ Organizational tenure } \\
\hline Below 1 year & 66 & 29.20 \\
\hline $1-5$ & 88 & 38.94 \\
\hline $6-10$ & 34 & 15.04 \\
\hline $11-15$ & 32 & 14.16 \\
\hline 16 and above & 6 & 2.66 \\
\hline Total & 226 & 100.00 \\
\hline \multicolumn{3}{|l|}{ Department } \\
\hline Restaurant service & 69 & 30.53 \\
\hline Culinary & 53 & 23.45 \\
\hline Front Office & 47 & 20.80 \\
\hline Housekeeping & 30 & 13.27 \\
\hline Guest relations & 20 & 8.85 \\
\hline Other & 7 & 3.10 \\
\hline Total & 226 & 100.00 \\
\hline
\end{tabular}

\section{Measurement Results}

In order to test the validity of the data, this study performed exploratory factor analysis (EFA). According to EFA results, factor loadings show acceptable values ranging between 0.62 and 0.94 . Therefore, all factor loadings have been significant and there are not cross-loadings (see Table 2).

However, one item from job security, two items from job satisfaction, and two items from turnover intensions scales were removed because of the cross loading. Finally, the exploratory factor analysis resulted in seven constructs showing eigenvalues over 1.00. The seven elements totally explained $73.4 \%$ of the 
variance extracted. Furthermore; Table 2 indicates Cronbach alpha coefficients. The Cronbach alpha coefficients exceed the threshold of 0.70 , and so all factors are reliable. The above-mentioned findings revealed that there was proof for convergent and discriminant validity. To control common method variance (CMV), Harman's one factor analysis has been carried out. The findings show that one factor cannot explain more that $50 \%$ of total variance $(27.3 \%)$. Therefore, CMV is not a problem for the current data set.

Table 2. Measurement parameter estimates

\begin{tabular}{|c|c|c|c|c|}
\hline Items & Eigenvalue & $\%$ of variance & $\alpha$ & Loadings \\
\hline Role conflict & 7.91 & 27.3 & .90 & \\
\hline \multicolumn{4}{|c|}{ 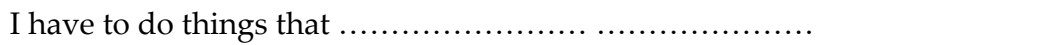 } & .72 \\
\hline \multicolumn{4}{|c|}{ I receive an assignment ....................................... } & .63 \\
\hline \multicolumn{4}{|c|}{ 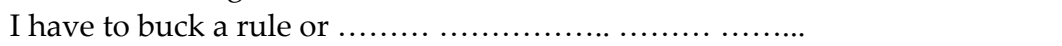 } & .73 \\
\hline \multicolumn{4}{|c|}{ 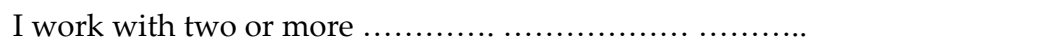 } & .79 \\
\hline \multicolumn{4}{|c|}{ 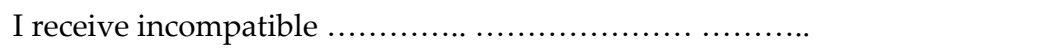 } & .83 \\
\hline \multicolumn{4}{|c|}{ I do things that are apt to be accepted $\ldots \ldots \ldots \ldots \ldots \ldots \ldots \ldots$} & .81 \\
\hline \multicolumn{4}{|c|}{ 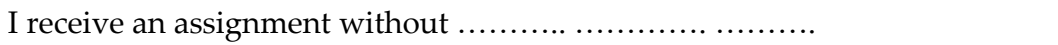 } & .75 \\
\hline \multicolumn{4}{|c|}{ 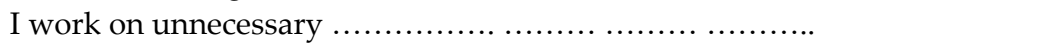 } & .70 \\
\hline Career opportun & s 4.14 & 14.3 & .97 & \\
\hline \multicolumn{4}{|c|}{ 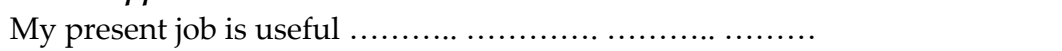 } & .92 \\
\hline \multicolumn{4}{|c|}{ My present job is relevant to ............................... } & .94 \\
\hline \multicolumn{4}{|c|}{ I feel that my present job will .............................. } & .93 \\
\hline \multicolumn{4}{|c|}{ 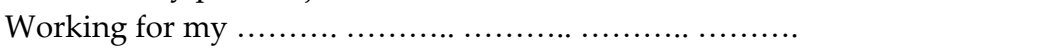 } & .91 \\
\hline \multicolumn{4}{|c|}{ I believe that my present $\ldots \ldots \ldots \ldots \ldots \ldots \ldots \ldots \ldots \ldots \ldots \ldots \ldots \ldots \ldots \ldots$} & .90 \\
\hline & & 10.9 & .82 & \\
\hline \multicolumn{4}{|c|}{ 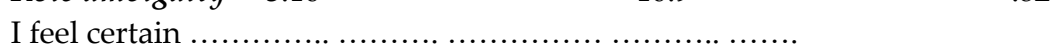 } & .62 \\
\hline \multicolumn{4}{|c|}{ 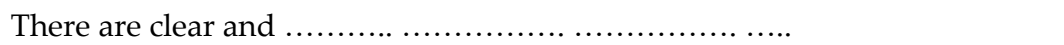 } & .79 \\
\hline \multicolumn{4}{|c|}{ 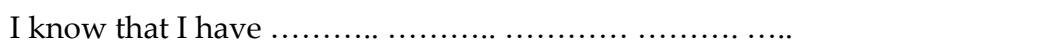 } & .75 \\
\hline \multicolumn{4}{|c|}{ 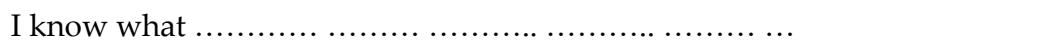 } & .62 \\
\hline \multicolumn{4}{|c|}{ 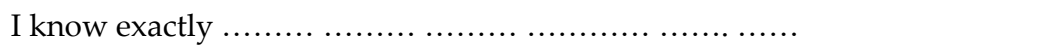 } & .79 \\
\hline \multicolumn{4}{|c|}{ Explanation is clear $\ldots \ldots \ldots \ldots \ldots \ldots \ldots \ldots \ldots \ldots \ldots \ldots \ldots$} & .68 \\
\hline Role overload & 2.15 & 7.4 & .79 & \\
\hline \multicolumn{4}{|c|}{ 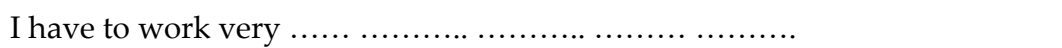 } & .69 \\
\hline \multicolumn{4}{|c|}{ My workload …......................................... } & .84 \\
\hline \multicolumn{4}{|c|}{ 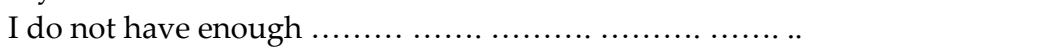 } & .78 \\
\hline Job security & & 5.2 & .78 & \\
\hline \multicolumn{3}{|c|}{ If my current organization. } & . & $-^{*}$ \\
\hline \multicolumn{4}{|c|}{ 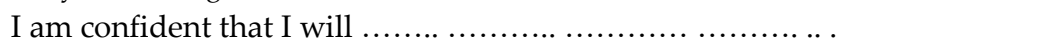 } & .82 \\
\hline \multicolumn{4}{|c|}{ Regardless of economic conditions....................... } & .71 \\
\hline \multicolumn{4}{|c|}{ 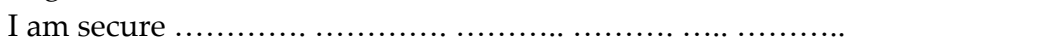 } & .76 \\
\hline Job satisfaction & 1.27 & 4.4 & .84 & \\
\hline Overall, I am ... & $\ldots \ldots \ldots \ldots \ldots \ldots$ & $\ldots \ldots \ldots \ldots \ldots \ldots$ & & $-{ }^{*}$ \\
\hline I intent to keep & . .................. & ................... & & $-{ }^{*}$ \\
\hline I often think .... & .................. & $\ldots \ldots \ldots \ldots \ldots \ldots$ & & .83 \\
\hline As soon as I can & $\ldots \ldots \ldots \ldots \ldots \ldots$ & ................... & & .80 \\
\hline Turnover intent & 1.16 & 4.0 & .80 & \\
\hline How likely is it & you will be ..... & $\ldots \ldots \ldots \ldots \ldots \ldots$ & & $-^{*}$ \\
\hline How likely is it th & u will ................ & … $\ldots \ldots \ldots \ldots \ldots \ldots$ & & .81 \\
\hline I will be with th & $\ldots \ldots \ldots \ldots \ldots$ & $\ldots \ldots \ldots \ldots \ldots \ldots \ldots$ & & $-*$ \\
\hline I will probably 1 & …............. & 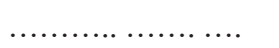 & & .76 \\
\hline
\end{tabular}

Note: KMO Measure of Sampling Adequacy=.80, Barletts' Test of Sphericity= 2637.1, df = 406, $p<.001$.

"Removed as a result of exploratory factor analysis. $\alpha$ denotes alpha coefficient. 
Table 3. Means, standard deviations, and correlations of research constructs

\begin{tabular}{|c|c|c|c|c|c|c|c|c|c|}
\hline Variables & Means & $\mathrm{SD}$ & 1 & 2 & 3 & 4 & 5 & 6 & 7 \\
\hline 1. Role conflict & 3.25 & 1.73 & - & & & & & & \\
\hline 2. Career opportunities & s 4.53 & 2.14 & $-.198^{*}$ & - & & & & & \\
\hline 3. Role ambiguity & 6.13 & 1.01 & $-.285^{* *}$ & .120 & - & & & & \\
\hline 4. Role overload & 3.84 & 1.89 & $.387^{* *}$ & $-.308^{* *}$ & -.094 & - & & & \\
\hline 5. Job security & 4.37 & 1.75 & -.142 & $.451^{* *}$ & $.278^{* *}$ & -.014 & - & & \\
\hline 6. Job satisfaction & 2.92 & 2.12 & $.317^{* *}$ & $-.246^{* *}$ & .002 & .116 & $-.175^{*}$ & - & \\
\hline 7. Turnover intentions & 2.94 & 1.87 & $.432^{* *}$ & $-.261^{* *}$ & $-.148^{*}$ & $.317^{* *}$ & $-.192^{*}$ & $-.397^{* *}$ & - \\
\hline
\end{tabular}

Note: Composite number for each factor was calculated by mean scores of items. SD means Standard Deviation.

Means, SDs, and correlations were shown in Table 3.According to this table, the predominance of the correlation coefficients were significant. Nevertheless, the correlations between CO and RA, between RA and RO, between RC and Job Security, between RO and Job security, between RA and JS, between RO and JS were not significant. According to the results both RC $(r=.432)$ and $\mathrm{RO}(r=.317)$ had significant and positive association with TI by employees. The results in Table 3 showed that both CO $(r=-.261)$ and JS $(r=-.192)$ were negatively associated with TI. Table 3 indicated that $\operatorname{RC}(r=.317)$ had positive significant association with JS while both CO ( $r=-.246)$, and Job Security $(r=-.175)$ had negative relation with JS, whereas RA and RO did not. Thus, RA and RO were not included in the mediation analysis. On the other hand, Table 3 represents that JS had a significant relation with TI $(r=-.397)$. In accordance with Baron and Kenny (1986), the influence of the mediator on the dependent should be more than the independent variable, when the mediator is added to equation. According to these results, when job satisfaction is controlled, the impact of $\mathrm{CO}$ on TI is non-significant.

Table 4. Hypothesis testing: Multiple regression analysis

\begin{tabular}{|c|c|c|c|c|c|c|c|}
\hline & & \multicolumn{6}{|c|}{ Dependent variables / Standardized Regression Weights } \\
\hline & & \multicolumn{2}{|l|}{ Job satisfaction } & \multicolumn{4}{|c|}{ Turnover intentions } \\
\hline & \multicolumn{2}{|r|}{ Step 1} & & \multicolumn{2}{|l|}{ Step 1} & \multicolumn{2}{|c|}{ Step 2} \\
\hline & $\beta$ & $t$ & & $\beta$ & $t$ & $\beta$ & $t$ \\
\hline Constructs & & & Variables & & & & \\
\hline Role conflict & .33 & $4.48^{*}$ & Role conflict & .40 & $4.87^{*}$ & .32 & $3.94 *$ \\
\hline Career opportunities & -.173 & $-1.73^{\circ}$ & Career opportun & es -.18 & $-2.25^{*}$ & -.13 & -1.66 \\
\hline Role ambiguity & .14 & 1.50 & & & & & \\
\hline Role overload & -.05 & -.56 & & & & & \\
\hline Job security & -.09 & -.90 & Job satisfaction & - & - & -.26 & $-3.17^{*}$ \\
\hline$F$ & 4.46 & - & $F$ & $17.21^{*}$ & - & -15.61 & - - \\
\hline$R^{2}$ at each step & .16 & - & $R^{2}$ at each step & .22 & - & .28 & - \\
\hline$\Delta R^{2}$ & - & - & $\Delta R^{2}$ & - & - & .06 & - \\
\hline \multicolumn{8}{|l|}{ Sobel test for: } \\
\hline \multicolumn{3}{|c|}{ Career opportunities $\rightarrow$ Job satisfaction $\rightarrow$ Turnover intentions } & \multicolumn{5}{|c|}{ 1.83. Note: There is no effect of multicollienarity $\mid \mathrm{p}<.10, " \mathrm{p}<.05$} \\
\hline
\end{tabular}

The results of regression models were shown in Table 4 as presented in the conceptual model in Figure 1. As reported in Table 4 , the coefficient of $\mathrm{RC}$ in the first model was positive and statistically significant $(\beta=.33, t$ $=4.48$ ); therefore, hypothesis one ( $\mathrm{H1a}$ ) could not be confirmed. The coefficient of $\mathrm{CO}$ was negative and 


\section{N. Çakmakoğlu Arıcı 11/4 (2019) 3374-3384}

statistically significant $(\beta=-.173, t=-1.73)$; therefore, H1e also could not be validated. Since the other coefficients in the first model were not statistically significant, the hypotheses H1b through H1d could not be confirmed or validated in this study. The regression table also shows that job satisfaction has a significant and negative effect on employee turnover intention $(\beta=-.26, t=-3.17)$, providing empirical support for $\mathrm{H} 2$.

The results demonstrated in Table 4 that job satisfaction fully mediated the relationships between career opportunities and turnover intentions, since there was not significant effect of career opportunities $(\beta=-.13, t$ $=-1.66$ ) on turnover intention, when the mediator was added to model. Thus, H3 was empirically supported on behalf of career opportunities. On the other hand, the results in Table 4 demonstrated that the job satisfaction reduced the size of effect of role conflict $(\beta=.32, t=3.94)$ on turnover intentions. Therefore, job satisfaction had partial mediation effect on the relationships between RC and TI. The results showed that the $R^{2}$ of the model significantly increased $\left(\Delta R^{2}=.06, p<.10\right)$. According to Sobel test (Sobel, 1982) result, test statistic was significant $(1.83, p<.10)$ which proved the impact of job satisfaction as a mediator on the effect of $\mathrm{CO}$ on TI by hotel employees. Results in Table 3 and Table 4 showed that the impact of job satisfaction as a mediator on the effects of role ambiguity, role overload, and job security on turnover intentions by frontline employees could not be inferred; therefore, the hypothesis of $\mathrm{H} 3$ could not be validated.

\section{DISCUSSION}

The main purpose of the study was to investigate the associations among job stressors, which were role conflict, role ambiguity, role overload, job security, and career opportunities; employee job satisfaction, and turnover intention for frontline employees of hotels in Antalya with reviewing carefully the literature that provides high-quality, delivering optimal services consider as a greater success in terms of hospitality and tourism (Tse, 2012). In the context of hotels in Antalya existing stress symptoms between front-line employees subsequently comprised contextual elements like a long-term work, huge or customers' demands, low degree of organizational support, and lack of stability in their work place. It was argued with the light of two main theories, Personality theory and Affect theory, how job satisfaction influenced and mediated the job stressors and turnover intention of the employees. This paper included a total of 226 employees to examine the conceptual modal proposed in Figure 1.

First, the findings unexpectedly demonstrate that there are no significant effects of such job stressors as role ambiguity, role overload, and job security on employee job satisfaction. These findings are incongruent with some of the previous empirical findings (e.g., Kim et al., 2009; Zeytinoglu et al., 2013).

Congruent with the findings of previous studies (Alniaçik et al., 2013; Huang et al., 2019; Jang \& George, 2012), the findings of the present study show that employee satisfaction has a negative and significant effect on employee turnover intention. Moreover, the argument made in the study was that job satisfaction of hotel frontline employees fully mediated the impacts of role conflict, role ambiguity, role overload, job security, and career opportunities on their turnover intention. The obtained results from correlation and regression analyses showed that it was career opportunities whose effect on employee intention to quit has been mediated by job satisfaction. Results also confirmed a partial mediating impact of job satisfaction on the effect of role conflict on employee intention to leave. The results on the mediating role of job satisfaction have also confirmed the empirical findings of previous research studies conducted in the hospitality literature (e.g., Chan \& Ao, 2019; DiPietro et al., 2019; Eşitti \& Kasap, 2019; Ohunakin et al., 2019).

\section{Management Implications}

This study reveals that hotel administrations should give stronger emphasis on providing career opportunities to augment employee job satisfaction and to reduce turnover intention of their employees. Results also showed that hotel administrations need to resolve conflicts of employees' role in order to increase their performance and enable them to increase their job satisfaction. It is understood that providing further career opportunities to employees and reducing conflicts in their positions and duties will result in higher employee satisfaction and lower intention to leave the job. Hotels, as an example, might arrange training programs towards their frontline employees at the times when employees will have new duties in their positions and provide work guides that will clearly describe role expectations and commitments to decrease role ambiguity and role conflict (Chen et al., 2011). Furthermore, hotels are to provide contemporary career opportunities for their employees and need to maintain contemporary strategic 


\section{N. Çakmakoğlu Arıcı 11/4 (2019) 3374-3384}

planning arrange training programs towards employees for better human capital and invest on infrastructure and equipment.

\section{Limitations and Future Research Directions}

This study has originally augmented job satisfaction dimension into the association among job stressors (role conflict, role ambiguity, role overload, job security, and career opportunities) and turnover intention by hotel frontline employees in Antalya, Turkey. Because this present research utilizes a convenience sampling, the results are not a representative sample utilizing any of the probability sampling methods, and so the findings cannot be generalized for all employees in Antalya and Turkey. The future studies can seek other sampling methods with different and more employees' positions. This paper was carried out only for Hotel Industry in Turkey. Hence, future studies can examine the mediating effect of job satisfaction in the other counties. The research can be extended to a greater segment of Antalya in order to see if results are similar. This time the proposed model can be also checked for robustness. It would be suggested for future researchers that career opportunities can moderate the relationship between gender and job performance within the organization.

\section{REFERENCES}

Alniaçik, E., Alniaçik, Ü., Erat, S. and Akçin, K. (2013). Does person-organization fit moderate the effects of affective commitment and job satisfaction on turnover intentions?, Procedia-Social and Behavioral Sciences, 99, 274-281.

Baron, R. M. and Kenny, D. A. (1986). Moderator-Mediator variables distinction in social psychological research: Conceptual, strategic, and statistical considerations, Journal of Personality and Social Psychology, 51 (6), 1173-1182.

Bedeian, A., Kemery, E. and Pizzolatto, A. (1991). Career commitment and expected utility of present job as predictors of turnover intentions and turnover behavior, Journal of Vocational Behavior, 39 (1), 331-343.

Beehr, T.A., Jex, S.M., Stacy, B.A. and Murray, M.A. (2000). Work stressors and coworker support as predictors of individual strain and job performance, Journal of Organizational Behavior, 21, 391-405.

Caplan, R. D., Cobb, S. and French, J. R. P. (1975). Relationship of cessation of smoking with job stress, personality, and social support, Journal of Applied Psychology, 60 (2), 211-219.

Carmeli, A., Reiter-Palmon, R. and Ziv, E. (2010). Inclusive leadership and employee involvement in creative tasks in the workplace: The mediating role of psychological safety, Creativity Research Journal, 22 (3), 250-260.

Chan, S. H. J. and Ao, C. T. D. (2019). The Mediating Effects of Job Satisfaction and Organizational Commitment on Turnover Intention, in the Relationships Between Pay Satisfaction and WorkFamily Conflict of Casino Employees, Journal of Quality Assurance in Hospitality \& Tourism, 20 (2), 206-229.

Chen, C. F. (2006). Job satisfaction, organizational commitment, and flight attendants' turnover intentions: A note, Journal of Air Transport Management, 12 (5), 274-276.

Chen, M. F., Lin, C. P. and Lien, G. Y. (2011). Modelling job stress as a mediating role in predicting turnover intention, The Service Industries Journal, 31 (8), 1327-1345.

Chi, C. G. and Gursoy, D. (2009). Employee satisfaction, customer satisfaction, and financial performance: An empirical examination, International Journal of Hospitality Management, 28 (1), 245-253.

Chou, R. J. and Robert, S. A. (2008). Workplace support, role overload, and job satisfaction of direct care workers in assisted living, Journal of Health \& Social Behavior, 49 (2), 208-222.

Davy, J. A., Kinicki, A. J. and Scheck, C. L. (1997). A test of job security's direct and mediated effects on withdrawal cognitions, Journal of Organizational Behaviour, 18 (4), 323-349. 


\section{N. Çakmakoğlu Arıcı 11/4 (2019) 3374-3384}

De Croon, E. M., Sluiter, J. K. and Blonk, R. W. B. (2004). Stressful work, psychological job strain, and turnover: A 2-year prospective cohort study of truck drivers, Journal of Applied Psychology, 89 (3), 442-454.

DiPietro, R. B., Moreo, A. and Cain, L. (2019). Well-being, affective commitment and job satisfaction: influences on turnover intentions in casual dining employees, Journal of Hospitality Marketing $\mathcal{E}$ Management, 1-25. DOI: 10.1080/19368623.2019.1605956.

Elangovan, A. R. (2001). Causal ordering of stress, satisfaction and commitment, and intention to quit: a structural equations analysis, Leadership \& Organization Development Journal, 22 (4), 159-165.

Eşitti, B. and Kasap, M. (2019). The impact of leader-member exchange on lodging employees' dynamic capacities: The mediating role of job satisfaction, Tourism and Hospitality Research, 1-8. DOI: $10.1177 / 1467358419826397$.

Huang, C., Wu, K. and Zhang, Y. (2019). Understanding precedents for frontline employee turnover in luxury hotels: Emotional intelligence as a unifying factor, Journal of Human Resources in Hospitality $\mathcal{E}$ Tourism, 18 (1), 26-46.

Ingersoll, G. L., Olsan, T., Drew-Cates, J., DeVinney, B. and Davies, J. (2002). Nurses' job satisfaction, organizational commitment, and career intent, Journal of Nursing Administration, 32 (5), 250-263.

Jackson, S. E., Schwab, R. L. and Schuler, R. S. (1987). Toward an understanding of the burnout phenomenon, Journal of Applied Psychology, 71 (4), 630-640.

Jang, J. and George, R. T. (2012). Understanding the influence of polychronicity on job satisfaction and turnover intention: A study of non-supervisory hotel employees, International Journal of Hospitality Management, 31 (2), 588-595.

Kahn, R. (1980). Conflict, Ambiguity, and Overload: Three Elements in Job Stress, in the study of organizations, Katz, D, Kahn, R, and Adams, J. (Eds.), Occupational Mental Health, San Francisco, CA, Jossey-Bass, 418-428.

Keller, R. T. (1975). Role conflict and ambiguity: Correlates with job satisfaction and values, Personnel Psychology, 28 (1), 57-64.

Kelloway, E.K. and Barling, J. (1990). Item content vs. item wording: Disentangling role conflict and role ambiguity, Journal of Applied Psychology, 75 (6), 738-742.

Kim, B. P., Murrmann, S. K., and Lee, G. (2009). Moderating effects of gender and organizational level between role stress and job satisfaction among hotel employees, International Journal of Hospitality Management, 28 (4), 612-619.

Kim, H. J., Shin, K. H. and Umbreit, W. T. (2007). Hotel job burnout: The role of personality characteristics, International Journal of Hospitality Management, 26 (2), 421-434.

LePine, J.A., Podsakoff, N.P. and LePine, M.A. (2005). A meta-analytic test of the challenge stressorhindrance stressor framework: an explanation for inconsistent relationships among stressors and performance, Academy of Management Journal, 48, 764-775.

Locke, E. A. (1976). The nature and causes of job satisfaction. Handbook of industrial and organizational psychology, Chicago, RandMc Narlly.

Mahdi, A. F., Zin, M. Z. M., Nor, M. R. M., Sakat, A. A. and Naim, A. S. A. (2012). The relationship between job satisfaction and turnover intention, American Journal of Applied Sciences, 9 (9), 1518-1526.

Mitchel, J. O. (1981). The effect of intentions, tenure, personal, and organizational variables on managerial turnover, The Academy of Management Journal, 24 (4), 742-751.

Mor Barak, M. E., Nissly, J. A. and Levin, A. (2001). Antecedents to retention and turnover among child welfare, social work, and other human service employees: What can we learn from past research? A review and meta-analysis, Social Service Review, 75 (4), 625-661. 
Ohunakin, F., Adeniji, A. A., Oludayo, O. A., Osibanjo, A. O. and Oduyoye, O. O. (2019). Employees' retention in Nigeria's hospitality industry: The role of transformational leadership style and job satisfaction, Journal of Human Resources in Hospitality \& Tourism, 18 (4), 441-470.

Oldham, G. R., Kulik, C. T., Ambrose, M. L., Stepina, L. P. and Brand, J. F. (1986). Relations between job facet comparisons and employee reactions, Organizational Behavior and Human Decision Processes, 38 (1), 2847.

Parvin, M. M. and Kabir, M. M. N. (2011). Factors affecting employee job satisfaction of pharmaceutical sector, Australian Journal of Business and Management Research, 1 (9), 113-123.

Rizzo, J. R., House, R. J. and Lirtzman, S. I. (1970). Role conflict and ambiguity in complex organizations, Administrative Science Quarterly, 15 (2), 150-163.

Schaubroeck, J., Cotton, J. L. and Jennings, K. R. (1989). Antecedents and consequences of role stress: A covariance structure analysis, Journal of Organizational Behavior, 10 (1), 35-58.

Semykina, A. and Linz, S. J. (2012). Job satisfaction and advanced career opportunities for women: an empirical investigation of workers in six formerly socialist economies. https://dx.doi.org/10.2139/ssrn.2070226 (Reached on September 4, 2019).

Sobel, M. E. (1982). Asymptotic confidence intervals for indirect effects in structural equation models, Leinhardt, S. (Ed.), Sociological Methodology, Washington DC, American Sociological Association, 290312.

Stordeur, S., D'hoore, W. and Vandenberghe, C. (2001). Leadership, organizational stress, and emotional exhaustion among hospital nursing staff, Journal of Advanced Nursing, 35, 533-542.

Tse, W. S. (2012). The role of personality in understanding job stress and employee selection of staff in hospitality industry, Journal of Tourism \& Hospitality, 1 (2), 1-2.

Zeytinoglu, I. U., Yılmaz, G., Keser, A., Inelmen, K., Uygur, D. and Özsoy, A. (2013). Job satisfaction, flexible employment and job security among Turkish service sector workers, Economic and Industrial Democracy, 34 (1), 123-144. 